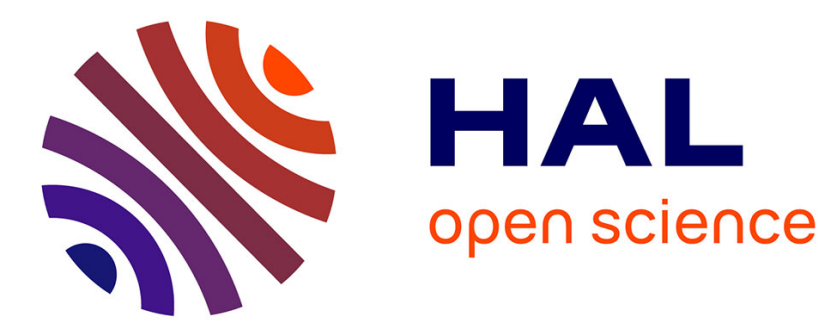

\title{
Inheritance of vegetative characters in pepper (Capsicum annuum L.)
}

Maria Luisa Gómez-Guillamón, Jesús Cuartero

\section{To cite this version:}

Maria Luisa Gómez-Guillamón, Jesús Cuartero. Inheritance of vegetative characters in pepper (Capsicum annuum L.). Agronomie, 1987, 7 (4), pp.271-277. hal-00884991

\section{HAL Id: hal-00884991 \\ https://hal.science/hal-00884991}

Submitted on 1 Jan 1987

HAL is a multi-disciplinary open access archive for the deposit and dissemination of scientific research documents, whether they are published or not. The documents may come from teaching and research institutions in France or abroad, or from public or private research centers.
L'archive ouverte pluridisciplinaire HAL, est destinée au dépôt et à la diffusion de documents scientifiques de niveau recherche, publiés ou non, émanant des établissements d'enseignement et de recherche français ou étrangers, des laboratoires publics ou privés. 


\title{
Inheritance of vegetative characters in pepper (Capsicum annuum L.)
}

\author{
Maria Luisa GÓMEZ-GUILLAMÓN and Jesús CUARTERO \\ Estación Experimental "La Mayora". (C.S.I.C.). Algarrobo (Málaga). Spain.
}

SUMMARY

The mode of inheritance of three characters, plant height, length of main stem, and length of first three internodes was studied in pepper plants using a complete diallel of 8 parental lines and their 56 hybrids. Cultivation was in a polyethylene greenhouse, with two environmental conditions : gravelled soil with drip irrigation, and bare soil with furrow irrigation. Additivity was the most important parameter. Intermediate inheritance for main stem length was found and also a weak partial dominance towards greater plant height and longer internodes. When the line derived from "Loreto 74 fruto fino" was the female parent, maternal influence on plant height and internode lengths was evident. However, in lines derived from both "Csokros felallo" and "Cubanelle", maternal effects were seen for the length of the main stem. Main stem length is suggested as a selection index for plant height for two reasons : (1) the genotypic correlation between both characters was very close $(0.97)$; (2) the main stem length character appeared early.

Additional key words : Plant height, main stem length, internode length, correlations.

Hérédité de caractères végétatifs chez le Piment (C. annuum L.).

Sur un essai diallèle complet se composant de 8 lignées parentales et de 56 hybrides réciproques entre ces lignées, on a étudié l'hérédité des caractères : hauteur totale de la plante, longueur de l'axe principal et longueur des 3 entrenœuds situés au-dessus de la première ramification. L'essai a été réalisé en serre suivant deux méthodes : culture sur sable avec arrosage goutte à goutte et culture en terre avec arrosage à la raie.

Les méthodes d'analyse de HAYMAN (1954) et Griffing (1956) ont été utilisées. Pour les 3 caractères étudiés, le paramètre génétique le plus important est l'additivité. On a révélé l'existence d'une hérédité de type intermédiaire pour la hauteur de l'axe principal et d'une dominance partielle vers des plantes plus hautes et des entrenœuds plus longs. On a observé des effets maternels pour les trois caractères. Ils sont dus aux descendants de « Loreto 74 fruto fino » pour la hauteur de la plante et la longueur des entrenœuds et aux descendants de " Csokros felallo » et "Cubanelle " pour la longueur de l'axe principal.

On suggère l'emploi, en sélection, du critère longueur de l'axe principal car il est en corrélation génotypique étroite (0.97) avec la hauteur totale de la plante et sa manifestation est bien antérieure.

Mots clés additionnels: Hauteur de la plante, longueur de l'axe principal, longueur des entrencuds, corrélations.

\section{INTRODUCTION}

Supportive staking for pepper cultivation is expensive and the higher the plant the greater the cost. Plants grow taller in polyethylene greenhouses, and their tissues tend to be more tender and fragile, so that they need more costly staking than in the field. Consequently, there is an economical incentive to study the inheritance mode of plant height and other related vegetative characters to breed stronger more compact hybrids which might be grown with less support and which would avoid crop losses from broken branches and premature fruit fall.
Pepper plant height was studied by NAGAICH et al. (1972), Popova \& MiHAilov (1976), AHMED et al. (1982) among others. Most of these authors used several varieties of chilli peppers, but their studies of character behaviour concern only one type of pepper and moreover, the environmental conditions mentioned in these published papers differ greatly from those in South East Spain reported in the present paper.

Total plant height may be conveniently divided into length of the main stem, and length of the main branches. Similarly, the total length of a branch may be considered as the aggregate of its internodal lengths. Main stem length and length of the first three 
internodes are characters that appear early, they are easier to measure, and are probably more simply inherited, than total height. They could have practical application in selective breeding experiments aimed at plant height improvement. A study of their inheritance mode and the correlations between them could be rewarding. Of course, both main stem length and length of the first three internodes have a definite intrinsic agronomic interest because varieties with very low main stems tend to expose the first fruits to the risk of rot from soil contact. In pepper plants, each node is a fructification point, therefore selective breeding aims to produce plants with short internodes because a high negative correlation is reported between length of the first three internodes and total yield (GómEZ-GuILLAMÓN, 1982).

\section{MATERIAL AND METHODS}

An 8-line complete diallel was carried out. Table 1 indicates the characteristics of the 8 lines and the varieties they derived from.

The 64 genotypes (56 $\mathrm{F}_{1}$ and 8 parental lines) were cultivated in two polyethylene greenhouses, one with gravelled soil and drip irrigation and the other with bare soil and furrow irrigation (gravel and soil respectively). Two replications were established for each environment.

The different genotypes were sown on Dec. 21st 1979. Each seed plot capacity was $280 \mathrm{cc}$. Bedding was made up of peat $(\mathrm{pH}=6.5)$ enriched with superphosphate $\left(\begin{array}{llll}18 & \% & \mathrm{P}_{2} \mathrm{O}_{5}\end{array}\right)$. Germination took place in a greenhouse covered with glass-fibre-reinforced polyester plates. When the plants had developed 5 to 10 true leaves, they were transferred to their planned cultivation environment.

\section{Cultivation Data :}

Planting date

Distance between plants

Distance between lines

Irrigations

Fertilizations

Harvest start

Harvest end

\begin{tabular}{cc} 
Gravel & Soil \\
$26 / \mathrm{II} / 80$ & $7 / \mathrm{III} / 80$ \\
$0.5 \mathrm{~m}$ & $0.4 \mathrm{~m}$ \\
$1.0 \mathrm{~m}$ & $0.5 \mathrm{~m}$ \\
\multicolumn{2}{c}{ Once a week } \\
$400 \mathrm{~N}, 200 \mathrm{P}_{2} \mathrm{O}_{5}, 600 \mathrm{~K}_{2} \mathrm{O}, 80 \mathrm{MgO}$ \\
$22 /$ IV $/ 80$ & $30 / \mathrm{V} / 80$ \\
$31 /$ VII $/ 80$ & $25 /$ VIII $/ 80$
\end{tabular}

Measurements of the following characters were carried out on 5 plants selected for their uniformity :

1) length $(\mathrm{cm})$ of the main stem from cotyledons to the first flower (measured on gravel, but not on bare soil) ;

2) length $(\mathrm{cm})$ of first three internodes, measured on one of the primary branches, randomly chosen ;

3) plant height $(\mathrm{cm})$. The selected criterion was the length up to the 10th node because pepper is an indeterminate growth species. For "Csokros felallo" however, it was only possible to measure to the 7 th node, this being the maximum height development of this genotype. The character was measured in plants from both environments because the error that could occur through not being able to distinguish the cotyledons in soil is less for plant height measurements than those for main stem length.

Averages per genotype and replication were studied by means of Hayman's variance analysis (HAYMAN, 1954) and Griffing's diallel analysis, Experimental Method 1, Model I (GRIFFING, 1956). The analyses for gravel and soil were carried out separately and the results were compared.

Phenotypic correlations among characters were taken directly from average phenotypic values, whilst genotypic and environmental correlations were calculated by means of variance-covariance analysis.

\section{RESULTS AND DISCUSSION}

\section{A. Plant height}

Genetic parameters (table 2 and 3) were less significant on soil than on gravel because of the greater error values observed on soil. This may be because on gravel the environmental factors were more controlled.

Additive variance was strongly exhibited (table 2) and explains most of the differences found among the genotypes. Dominance was also significant, but it was less than that of additive variance. The differences between reciprocal crosses partly explain the dominance effects (MATHER \& JINKS, 1971). Hybrid heights were intermediate between those of their parents, but there were dominance effects towards

TABLE 1

Parental lines used and their characteristics.

Lignées parentales utilisées et leurs caractéristiques.

\begin{tabular}{|c|c|c|c|c|c|c|c|c|}
\hline & \multirow[b]{2}{*}{ N. Varieties } & \multirow[b]{2}{*}{ Origin } & \multicolumn{5}{|c|}{ Average phenotypic values } & \multirow[b]{2}{*}{$\otimes$} \\
\hline & & & $\begin{array}{l}\text { Plant } \\
\text { height } \\
(\mathrm{cm})\end{array}$ & $\begin{array}{c}\text { Main stem } \\
\text { length } \\
(\mathrm{cm})\end{array}$ & $\begin{array}{l}1-3 \text { inter- } \\
\text { node length } \\
\quad(\mathrm{cm})\end{array}$ & $\begin{array}{l}\text { Fruit } \\
\text { weight } \\
\text { (g) }\end{array}$ & $\begin{array}{l}\text { Main stem } \\
\text { true leaves }\end{array}$ & \\
\hline 1 & Dulce Italiano & Spain & 92 & 17.9 & 23.5 & 93 & 12 & 3 \\
\hline 2 & Cristal & Spain & 118 & 19.1 & 24.1 & 56 & 13 & 3 \\
\hline 4 & Pabellón fruto claro & México & 159 & 24.7 & 29.4 & 21 & 16 & 3 \\
\hline 5 & Loreto 74 fruto fino & México & 149 & 21.2 & 27.6 & 10 & 14 & 3 \\
\hline 6 & Csokros felallo & Hungary & 32 & 16.0 & 15.7 & 47 & 14 & 3 \\
\hline 7 & Valenciano & Spain & 103 & 16.8 & 24.2 & 132 & 14 & 3 \\
\hline 8 & California Wonder & U.S.A. & 74 & 14.5 & 20.0 & 131 & 13 & 2 \\
\hline
\end{tabular}

$\otimes=$ Self-pollinated generations. Générations d'autofécondation. 
TABLE 2

Results of Hayman's variance analysis for the three characters studied. Résultats de l'analyse de la variance de Hayman pour les trois caractères étudiés.

\begin{tabular}{|c|c|c|c|c|c|}
\hline \multirow[b]{2}{*}{ Sources of Variation } & \multirow[b]{2}{*}{ D.F. } & \multirow[b]{2}{*}{ Environment } & \multicolumn{3}{|c|}{ Mean Squares } \\
\hline & & & $\begin{array}{l}\text { Plant } \\
\text { height }\end{array}$ & $\begin{array}{l}\text { Main stem } \\
\text { length (1) }\end{array}$ & $\begin{array}{l}\text { 1-3 internodes } \\
\text { length }\end{array}$ \\
\hline Genotypes & 63 & $\begin{array}{l}\text { Gravel } \\
\text { Soil }\end{array}$ & $\begin{array}{l}192^{* * *} \\
206^{* * *}\end{array}$ & $2^{39^{* * *}}$ & $\begin{array}{l}30^{* * * *} \\
27^{* * *}\end{array}$ \\
\hline Additivity & 7 & $\begin{array}{l}\text { Gravel } \\
\text { Soil }\end{array}$ & $\begin{array}{l}1493^{* * *} \\
1569^{* * *}\end{array}$ & $\begin{array}{l}249^{* * *} \\
-\end{array}$ & $\begin{array}{l}210^{* * *} \\
169^{* * *}\end{array}$ \\
\hline Dominance & 28 & $\begin{array}{l}\text { Gravel } \\
\text { Soil }\end{array}$ & $\begin{array}{l}33^{* * *} \\
44^{*}\end{array}$ & $\underbrace{9^{* * *}}$ & $\begin{array}{r}9^{* * *} \\
12^{* * *}\end{array}$ \\
\hline b1 & 1 & $\begin{array}{l}\text { Gravel } \\
\text { Soil }\end{array}$ & $\begin{array}{l}153^{* * *} \\
258^{*}\end{array}$ & $1801 \mathrm{NS}$ & $\begin{array}{c}283^{* *} \\
1065^{* * *}\end{array}$ \\
\hline b2 & 7 & $\begin{array}{l}\text { Gravel } \\
\text { Soil }\end{array}$ & $\begin{array}{l}29 * * \\
56^{*}\end{array}$ & $\begin{array}{c}1379^{*} \\
-\end{array}$ & $\begin{array}{c}102^{* *} \\
81 \mathrm{NS}\end{array}$ \\
\hline b3 & 20 & $\begin{array}{l}\text { Gravel } \\
\text { Soil }\end{array}$ & $\begin{array}{l}29 * * * \\
29 \mathrm{NS}\end{array}$ & $\begin{array}{c}667 \mathrm{NS} \\
-\end{array}$ & $\begin{array}{l}69^{* *} \\
84 \mathrm{NS}\end{array}$ \\
\hline Maternal effects & 7 & $\begin{array}{l}\text { Gravel } \\
\text { Soil }\end{array}$ & $\begin{array}{l}27 * * \\
27 \mathrm{NS}\end{array}$ & $\underline{1}^{*}$ & $\begin{array}{c}7^{* *} \\
10 \mathrm{NS}\end{array}$ \\
\hline Reciprocal differences & 21 & $\begin{array}{l}\text { Gravel } \\
\text { Soil }\end{array}$ & $\begin{array}{l}25^{* * *} \\
27 \mathrm{NS}\end{array}$ & $\begin{array}{l}16^{* * *} \\
-\end{array}$ & $\begin{array}{l}6^{* *} \\
6 \text { NS }\end{array}$ \\
\hline Replications & 1 & $\begin{array}{l}\text { Gravel } \\
\text { Soil }\end{array}$ & $\begin{array}{l}11 \mathrm{NS} \\
109^{*}\end{array}$ & $\begin{array}{l}350^{* * *} \\
-\end{array}$ & $\begin{array}{r}39^{* * *} \\
219^{* * *}\end{array}$ \\
\hline Error & 63 & $\begin{array}{l}\text { Gravel } \\
\text { Soil }\end{array}$ & $\begin{array}{r}8 \\
21\end{array}$ & 5 & $\begin{array}{l}3 \\
5\end{array}$ \\
\hline
\end{tabular}

$*: 0.05>\mathrm{p}>0.01 ; * *: 0.01>\mathrm{p}>0.001 ;{ }^{* * *}: \mathrm{p}<0.001 ;$ NS $:$ Not significant.

b1 : differences between parental and progeny means ; b2 : asymmetry ; b3 : SCA effects.

(1) : length of main stem was only measured on gravel.

Mean squares of additivity and dominance were compared with maternal effects and reciprocal differences respectively, when these effects were significant.

b1 : différences entre pères et fils; $b 2$ : asymétrie dans la distribution des gênes; b3 : effets dus à l'ASC.

(1) : la longueur de l'axe principal a été mesurée seulement dans la culture sur sable.

Les carrés moyens de l'additivité et la dominance ont été comparés avec les effets maternels et avec les différences entre croisements réciproques respectivement, quand ces effets ont été significatifs.

greater height. These circumstances complicate selective breeding for character improvement. The fact that two groups of genes are involved in character inheritance, one with additive effects and one without, is reported by SoH et al. (1976), MilkovA (1977), SiNGH \& SiNGH (1976b) and AHMED et al. (1982). Although in this present work, additivity was the most important effect, SINGH \& SINGH (1976a) establish that dominance is more important than additivity for plant height inheritance.

On gravel, maternal effects were observed (table 2) and are attributed to line 5, derived from "Loreto 74 fruto fino", which produces higher plants when used as a mother than when used as a father.

W/V graphics (fig. 1a, 1b, 1c, 1d) show a good fit to the regression line of unit slope. Distribution of the parentals was more consistent on gravel than on soil and agrees with the greater significance for dominance effects observed on gravel. "Csokros felallo" (No. 6) was the parental with most recessive genes while "Loreto 74 fruto fino" (No. 5) was the parental with most genes for greater plant height.

Differences were observed between the replications of soil environment, but these were not seen in those of gravel (table 2), probably because water and fertilizer distribution were more homogeneous in the latter environment. One of the soil replications had soil with more clay, and this retained more water and produced higher plants.

Heritabilities were high : $h_{b}=0.93$ and $h_{n}=0.87$ on gravel and $h_{b}=0.83$ and $h_{n}=0.78$ on soil. The calculated values of broad heritability were very similar to those of DUTTA et al. (1979) for chilli peppers, and to those of ARYA \& SAINI (1976) for sweet peppers. The narrow heritability values were similar to those of SINGH \& SINGH (1977). The small contribution of dominance may be deduced from the small differences between the broad and narrow heritabilities.

Griffing's variance analysis (table 3 ) showed that both General Combining Ability (GCA) and Specific Combining Ability (SCA) were significant (in agreement with the results reported by SOH et al. (1976)). Variance-component estimations indicate that the GCA effects were, by far, the most important.

The lines with greatest GCA values, which generally produce the tallest descendants, were derived from "Pabellón fruto claro" and "Loreto 74 fruto fino". The lowest GCA values belonged to the lines derived from "Csokros felallo" and "California Wonder" ; the former is a determinate growth plant. The high correlation between the average phenotypic parental values and their GCA values $(0.97$ on gravel and 0.94 on soil) indicates that the parental phenotype may serve as an index of their GCA. Consequently, parental 

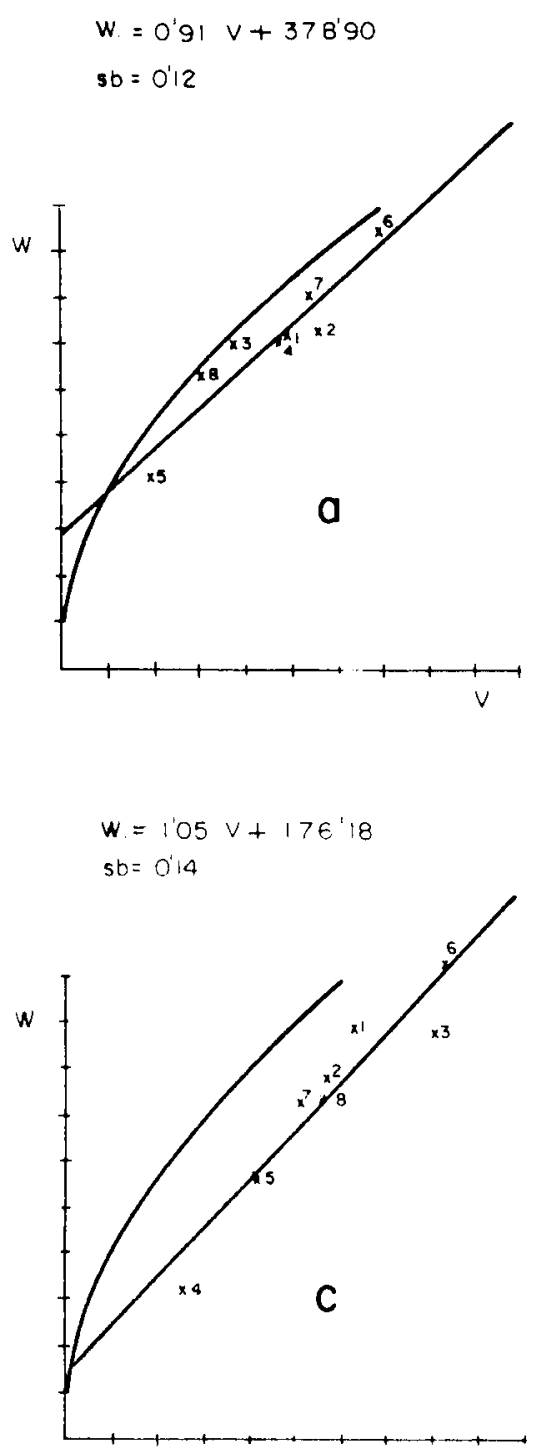

Figure 1

Plant height. $W / V$ graphs of diallel analysis. Replications given separately $: 1 a=$ Replication I/gravel $; I b=$ Replication II/gravel ; $I c=$ Replication $I /$ soil $; 1 d=$ Replication $I I /$ soil .

phenotypes may be employed to predict hybrid heights with a high degree of certainty.

\section{B. Length of the main stem}

The use of Hayman's variance analysis revealed significant differences among genotypes (table 2). Additivity was by far the most important parameter and the observed differences among genotypes could be attributed to it. The results show that the main stem length of hybrids were intermediate between those of their parents. Dominance also appeared to be significant, but the significance could be explained by the differences between reciprocal crosses (MATHER \& JINKS, 1971).

The distribution of parentals on $\mathrm{W} / \mathrm{V}$ graphics (fig. $2 \mathrm{a}$ and $2 \mathrm{~b}$ ) was not constant when the results of both replications were compared and this confirms the small importance of dominance effects for this character.

The maternal effects were due to lines 3 and 6 ,

$$
\begin{aligned}
& w=092 v+297^{\prime} 43 \\
& s b=0^{\prime} 12
\end{aligned}
$$

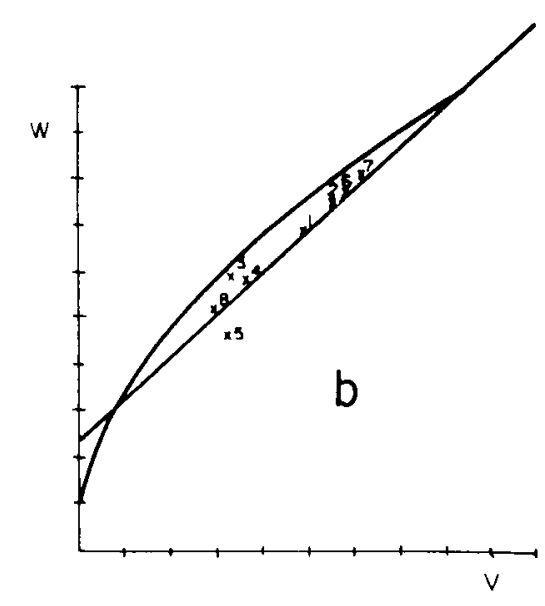

$$
w=084 v+379^{\prime} 71
$$$$
s b=0^{\prime} 19
$$

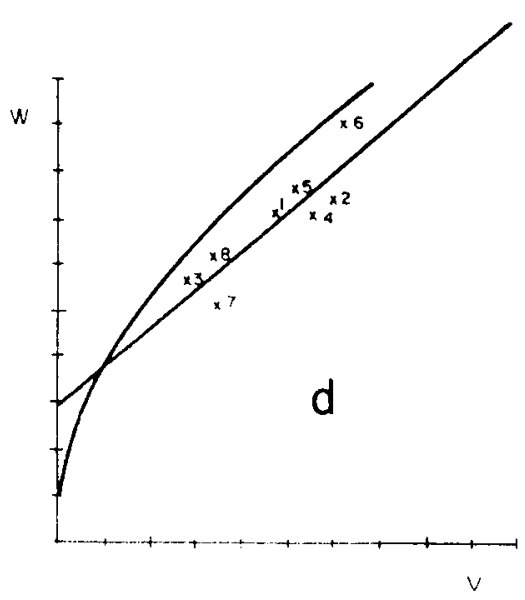

Hauteur totale de la plante. Graphiques $W / V$ de l'analyse diallèle. On donne les répétitions séparément : Ia = Répétition $\mathrm{I} /$ sable; $I b=$ Répétition $I I /$ sable $; I c=$ Répétition $I /$ terre $; l d=$ Répétition II/terre.

respectively derived from "Cubanelle" and "Csokros felallo" which tend to reduce the size of their descendants when they are used as female parents.

There were also significant differences between replications (table 2). Plants belonging to the replication cultivated in the warmest situation developed longer main stems.

Heritabilities were 0.78 in a broad sense, and 0.74 in a narrow sense ; the small difference between both calculations confirms the importance of additivity.

Griffing's variance analysis shows that GCA was the parameter with greatest influence over main stem length (table 3). Those parents with greatest GCA values were the lines derived from "Loreto 74 fruto fino", "Pabellón fruto claro" and "Valenciano" which generally produced hybrids with longer main stems. The lines with less GCA were derived from "Csokros felallo" and "Cubanelle".

SCA effects also appeared to be significant (table 3), but according to the variance components, their action was very weak and much less important than GCA. 


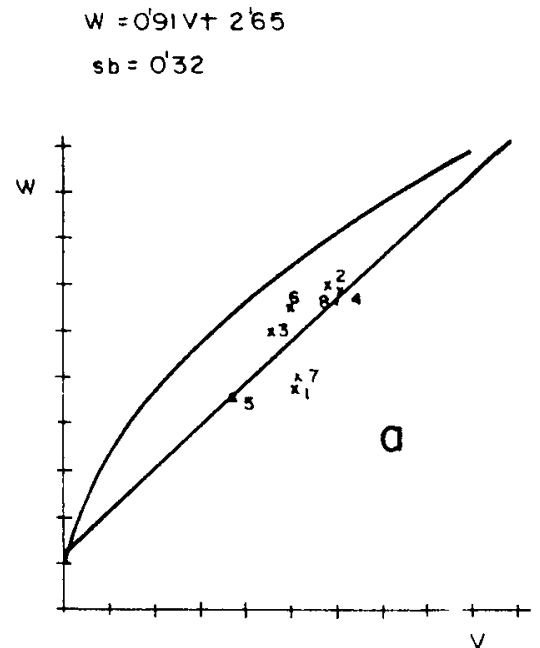

Figure 2

Length of main stem. W/V graphs of diallel analysis. Replications given separately: $2 a=$ Replication I/gravel $; 2 b=$ Replication II/gravel.
$W=0^{\prime} 90 V+307$

$s b=0^{\prime} 08$

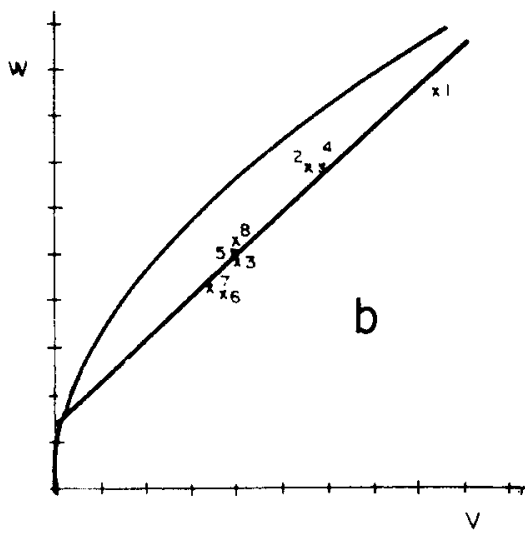

Longueur de l'axe principal. Graphiques $W / V$ de l'analyse diallèle. On donne les répétitions séparément : $2 a=$ Répétition $I /$ sable; $2 b=$ Répétition II/sable.

TABLE 3

Results of Griffing's variance analysis for the three characters studied. Résultats de l'analyse de la variance de Griffing pour les trois caractères étudiés.

\begin{tabular}{|c|c|c|c|c|c|c|c|c|}
\hline \multirow[t]{2}{*}{ Sources of Variation } & \multirow[t]{2}{*}{ D.F. } & \multirow[t]{2}{*}{ Environment } & \multicolumn{2}{|c|}{$\begin{array}{c}\text { Plant } \\
\text { height }\end{array}$} & \multicolumn{2}{|c|}{$\begin{array}{l}\text { Main stem } \\
\text { length (1) }\end{array}$} & \multicolumn{2}{|c|}{$\begin{array}{l}\text { 1-3 internodes } \\
\text { length }\end{array}$} \\
\hline & & & M.S. & $\sigma$ & M.S. & $\sigma$ & M.S. & $\sigma$ \\
\hline GCA & 7 & $\begin{array}{l}\text { Gravel } \\
\text { Soil }\end{array}$ & $\begin{array}{l}7460^{* * *} \\
7855^{* * *}\end{array}$ & $\begin{array}{l}464 \\
485\end{array}$ & $\begin{array}{c}128^{* * * *} \\
-\end{array}$ & $\begin{array}{l}786 \\
-\end{array}$ & $\begin{array}{r}105^{* * *} \\
85^{* * *}\end{array}$ & $\begin{array}{l}649 \\
515\end{array}$ \\
\hline SCA & 28 & $\begin{array}{l}\text { Gravel } \\
\text { Soil }\end{array}$ & $\begin{array}{l}165^{* * *} \\
218^{*}\end{array}$ & $\begin{array}{l}127 \\
116\end{array}$ & $\frac{5^{*}}{-}$ & $\frac{212}{-}$ & $\begin{array}{l}4^{* * *} \\
6^{* * *}\end{array}$ & $\begin{array}{l}303 \\
355\end{array}$ \\
\hline Reciprocal differences & 28 & $\begin{array}{l}\text { Gravel } \\
\text { Soil }\end{array}$ & $\begin{array}{l}126^{* * *} \\
138 \mathrm{NS}\end{array}$ & 31 & $8^{8^{* * *}}$ & $\begin{array}{c}273 \\
-\end{array}$ & $\begin{array}{l}3^{* *} \\
3 \mathrm{NS}\end{array}$ & - \\
\hline Error & 63 & $\begin{array}{l}\text { Gravel } \\
\text { Soil }\end{array}$ & $\begin{array}{r}38 \\
102\end{array}$ & & 2 & & $\begin{array}{l}1 \\
2\end{array}$ & \\
\hline
\end{tabular}

${ }^{*}: 0.05>\mathrm{p}>0.01 ;{ }^{* *}: 0.01>\mathrm{p}>0.001 ;{ }^{* * *}: \mathrm{p}<0.001 ;$ NS $:$ Not significant.

$\sigma:$ variance component as an indication of the relative importance of variation sources.

(1) : length of main stem was only measured on gravel.

Error mean squares have been obtained from block variance analysis.

$\sigma$ : composante de la variance, indicateur de l'importance relative des sources de la variation.

(1) : la longueur de l'axe principal a été mesurée seulement dans la culture sur sable.

Les carrés moyens de l'erreur ont été obtenus par l'analyse de la variance des blocs.

\section{Length of the first three internodes}

Analysis revealed that the less homogeneous environmental conditions of the soil cultivation method in comparison with the gravel method increased the error value in the soil method.

The additivity effects were significant according to Hayman's variance analysis (table 2). Dominance, while significant, was less important than additivity. There was a tendency towards longer internode dominance. Consequently, short internode parents have to be selected to get shorter internode hybrids.

On gravel, maternal effects (table 2) were attributed to the line derived from "Loreto 74 fruto fino" which produced longer internode descendants when used as a female parent than when used as a male parent.
The fits of the regression line of unit slope on $\mathrm{W} / \mathrm{V}$ graphics were not as good for the soil method as those for the gravel method because the soil environment was less controlled than that of gravel. Consequently, valid deductions could only be made from gravel $\mathrm{W} / \mathrm{V}$ graphics (fig. 3a and 3b). The lines derived from "Cristal" (No. 2), "Csokros felallo" (No. 6) and "Valenciano" (No. 7) had the most recessive genes for this character. "Loreto 74 fruto fino"' (No. 5) was the parent with the longest first three internodes.

Significant differences were detected between replications (table 2), both gravel and soil plant internodes were longer for those replications which had greatest soil humidity. This supports SERRANO (1974) who also finds longer internodes in plants from soils with higher humidity. 


$$
\begin{aligned}
& w=1^{\prime} 08 v+2^{\prime} 21 \\
& s b=0^{\prime} 28
\end{aligned}
$$

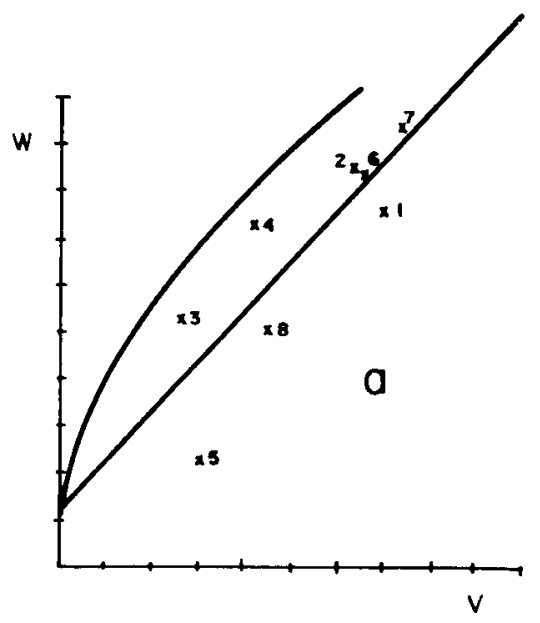

Figure 3

Length of the first three internodes. W/V graphs of diallel analysis. Replications given separately : $3 a=$ Replication $1 /$ gravel ; $3 b=$ Replication II/gravel.

Heritabilities were high in both environments : $h_{b}=0.85$ and $h_{n}=0.76$ on gravel and $h_{b}=0.71$ and $\mathrm{h}_{\mathrm{n}}=0.61$ on soil. These differences indicate a slight dominance effect.

Griffing's variance analysis (table 3) revealed the great importance of GCA effects. The lines with greatest GCA values derived from "Loreto 74 fruto fino" and "Pabellón fruto claro". Parents that produced hybrids with shorter internodes (lower GCA value) derived from "Cubanelle", "Csokros felallo" and "California wonder" varieties. Among these parental lines, "California wonder" produced the hybrids with the shortest internodes. "Csokros felallo" also had an interesting GCA value, but it is a very different cultivar with determinate growth and an average height of $32 \mathrm{~cm}$. "Cubanelle" had a very short main stem and so its use as a parent for internode length improvement would be counter-productive for main stem length improvement.

SCA was also significant (table 3). The variance components indicated that its effects must be taken into account.

\section{Relationships between characters}

Close relationships were found between all the 3 characters studied. Genetically, plant height was highly correlated with main stem length $\left(\mathrm{r}_{\mathrm{G}}=0.97\right)$ and also with overall length of the first three internodes length $\left(\mathrm{r}_{\mathrm{G}}=0.87\right)$. For both characters, the environmental correlations were low $\left(r_{E}=0.29\right.$ for main stem length, and $r_{E}=0.33$ for the overall length of the first three internodes). Consequently, not all the environmental factors that affect plant height influenced the other characters. For example, we observed that although greater soil humidity levels produced higher plants and longer internodes, it did not produce greater main stem lengths.

$$
w=0^{\prime} B 1 v+3^{\prime} 5 t
$$$$
s b=d_{13}
$$

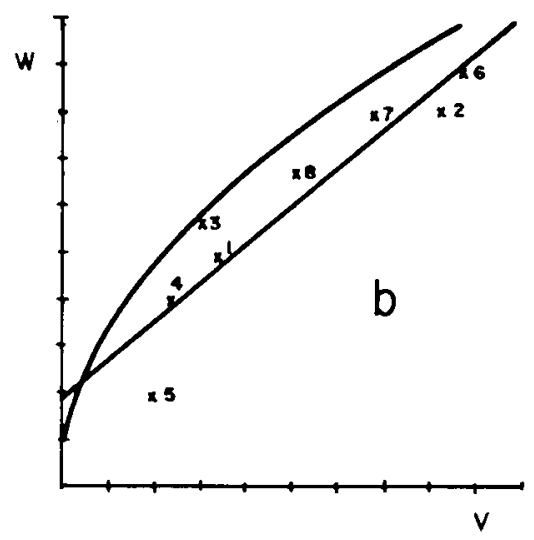

Longueur des trois premiers entrenœuds. Graphiques $W / V$ de l'analyse diallèle. On donne les répétitions séparément: $3 a=$ Répétition I/sable ; $3 b=$ Répétition II/sable.

Possibly however, this behaviour was influenced by the cultivation cycle employed. At the time of planting (November), temperatures were low, and this might have been the limiting factor of plant growth during these initial development stages because normally, the higher the temperatures the longer the main stems. Nevertheless, in the later stages of plant development the temperatures increased, and therefore other environmental factors, for example, soil humidity level and length of day, would also have influenced the internode growth and total height of the plant.

Considering the significant correlation between the replications, internode growth appeared to be more affected by humidity than plant height (table 2).

Main stem length showed a total genetic correlation with internode length $\left(r_{G}=1.00\right)$ and the phenotypic correlation was 0.74 . No environmental correlation was found $\left(r_{E}=0.05\right)$ which suggests that the environmental factors which favoured main stem length were independent from those for internode growth and this fact confirms our previous suppositions. Because the main stem length character is the earliest to show itself, it is the most appropriate measurement to select plants with the desired height and internode length.

\section{CONCLUSIONS}

The characters studied exhibited a similar inheritance mode, and additivity was clearly the most important genetic parameter. Nevertheless, the fact that some effects were due to dominance towards longer internodes and taller plants must be taken into account.

The greater significance of the GCA effects for the three characters, together with the significant correlations found between the GCA values and the parental phenotypic values suggest that the values of the phenotypic series might serve as an index to cal- 
culate the GCA values of the studied varieties. The results also suggest that to obtain genotypes with longer main stems, longer internodes, and greater plant heights, it would be best to include varieties "Loreto 74 fruto fino" and "Pabellón fruto claro", which might be expected to contribute a slight dominance. On the other hand, "Csokros felallo" and "California wonder" would be the recommended parental varieties to give genotypes with short main stems, short internode lengths and lower plants.

The three characters exhibited very close genotypic and phenotypic correlations. Thus, main stem length could be used as a selection index to predict internode length and plant height.
Under the cultivation conditions described, and with the varieties employed, environmental influence was important for phenotypic character expression. For main stem length, cultivation temperature seems to be the limiting factor. For plant height and internode length, it is soil humidity.

Reçu le 23 mai 1985. Accepté le 15 janvier 1987.

\section{ACKNOWLEDGEMENTS}

We would like to thank Mr. David W. Schofield for his helpful suggestions in editing and translating the manuscript.

\section{REFERENCES}

Ahmed N., Singh J., Virk D. S., 1982. Inheritance of some quantitative characters in chilli pepper (C. annuum L.). II. Earliness, seed number, fruit weight and plant height. Capsicum Newsletter, 1, 31.

Arya P. S., Saini S. S., 1976. Genetic variability and correlation studies in bell pepper. Indian J. agric. Res., 10 (4), 223-228.

Dutta M., Dasgupta P. K., Chatterjee S. D., Majumder M. K., 1979. Variability, interrelationships and path-coefficient analysis for some quantitative characters in chilli (C. annuum L.). Indian Agric., 23 (2), 95-102.

Gómez-Guillamón M. L., 1982. Genética de caracteres aplicables a la mejora del pimiento ( $\mathrm{C}$. annuum $L$.) en cultivo bajo invernadero. Tesis Doctoral. Universidad de Málaga (Espana), 358 pp.

Griffing B., 1956. Concept of general and specific combining ability in relation to diallel crossing systems. Aust. J. biol. Sci., 9, 463-493.

Hayman B. J., 1954. The theory and analysis of diallel crosses. Genetics, 39, 789-809.

Mather K., Jinks J. L., 1971. Biometrical Genetics. Chapman \& Hall Ltd., London, 2nd ed., 382 pp.

Milkova L., 1977. General and specific combining ability for plant height in a diallel cross of $C$. annuum L. In : Plant Breed. Abstr., 1978, 3719.
Nagaich B. B., Seihi J., Chaubey I. P., 1972. Inheritance of characters and heterosis in Capsicum sp. Haryana J. hortic. Sci., 1 (1-4), 69-75.

Popova D., Mihailov L., 1976. Inheritance of some quantitative characters on heterotic combinations of pepper (C. annuum L.). Genét. agrar., 30, 399-406.

Serrano Z., 1974. Cultivos Hortícolas Enarenados. Ministerio de Agricultura, Madrid, 1st ed., $559 \mathrm{pp}$.

Singh A., Singh H. N., 1976a. Inheritance of quantitative characters in chilli. Indian J. Genet. Plant Breed., 36 (3), 420-424.

Singh A., Singh H. N., 1976b. Genetic divergence in chilli. Indian J. Genet. Plant Breed., 36 (3), 425-430.

Singh A., Singh H. N., 1977. Note on heritability, genetic advance and minimum number of genes in chilli. Indian J. agric. Sci., 47 (5), 260-262.

Soh A. C., Yap T. C., Graham K. M., 1976. Heterosis and combining ability in a diallel cross of chilli. J. agric. Sci., 87, 447-449.

We would like to thank Mr. David W. SCHOFiELD for his helpful suggestions in editing and translating the manuscript. 